\title{
MENINGKATKAN KEMAMPUAN BERPIKIR KRITIS DAN HASIL BELAJAR HIDROKARBON MENGGUNAKAN MODEL PEMBELAJARAN PROBLEM BASED LEARNING (PBL)
}

\section{Improve Critical Thinking Skill And Learning Outcomes Hydrocarbons Using a Model of Problem Based Learning (PBL)}

Nur Husnina Lathifah*, Muhammad Kusasi, Rusmansyah

Program Studi Pendidikan Kimia FKIP Universitas Lambung Mangkurat, Jl. Brigjen H. Hasan Basry Banjarmasin 70123 Kalimantan Selatan Indonesia *email: 1stdy00@gmail.com

\begin{abstract}
Abstrak. Telah dilakukan penelitian tentang meningkatkan kemampuan berpikir kritis dan hasil belajar siswa menggunakan model pembelajaran Problem Based Learning (PBL) pada materi Hidrokarbon kelas X-3 SMA Negeri 10 Banjarmasin tahun pelajaran 2016/2017. Penelitian ini bertujuan untuk mengetahui (1) peningkatan aktivitas guru, (2) peningkatan aktivitas siswa, (3) peningkatan kemampuan berpikir kritis siswa, (4) peningkatan hasil belajar siswa, dan (5) respon siswa. Penelitian menggunakan rancangan penelitian tindakan kelas (PTK) dengan 2 siklus yang terdiri dari tahap perencanaan, pelaksanaan tindakan, pengamatan dan refleksi. Sampel penelitian adalah kelas X-3 dengan jumlah siswa 35 orang. Data dianalisis dengan teknik analisis deskriptif kuantitatif, dan analisis kualitatif. Hasil penelitian menunjukkan bahwa (1) terjadi peningkatan aktivitas guru dari 38,62 (cukup) pada siklus I menjadi 54,75 (sangat baik) pada siklus II, (2) terjadi peningkatan aktivitas siswa dari 35,9 (cukup) pada siklus I menjadi 49,3 (aktif) pada siklus II, (3) terjadi peningkatan kemampuan berpikir kritis siswa dari 55,64\% (cukup kritis) pada siklus I menjadi $71,74 \%$ (kritis) pada siklus II, (4) terjadi peningkatan ketuntasan hasil belajar kognitif $37,14 \%$ pada siklus I menjadi $74,28 \%$ pada siklus II, dan pada ranah afektif cukup pada siklus I menjadi baik pada siklus II, (5) siswa memberikan respon positif dengan kategori baik pada pembelajaran.
\end{abstract}

Kata kunci: kemampuan berpikir kritis, hasil belajar, problem based learning, hidrokarbon.

\begin{abstract}
The research about the improve critical thinking skills and learning outcomes hydrocarbons using a model of Problem Based Learning (PBL) at class X-3 of SMA Negeri 10 Banjarmasin leasson year 2016/2017 has done. This research aims to knowing (1) the improvement activity of teachers, (2) the improvement activity of students, (3) the improvement critical thinking skills of students, (4) the improvement learning outcomes of students, and (5) response of students. The study design was a classroom action research (PTK) with two cycles that composed of planning stage, implementation of actions, observation and reflection. Research sample is classroom X-3 with the number of students 35 person. Data were analyzed by using descriptive analysis of quantitative, and qualitative analysis. The result shows that (1) an increase in activity of 38,62 of teachers (enough) in the first cycle to 54,75 (excellent) on the second cycle, (2) an increase in the activity of students of 35,9 (enough) in the first cycle to 49,3 (active) on the second cycle, (3) an increase in critical thinking skill of students of 55,64\% (quite critical) in the first cycle to $71,74 \%$ (critical) in the second cycle, (4) completeness increase cognitive learning outcomes of $37,14 \%$ in the first cycle to $74,28 \%$ on the second cycle, and on affective domain quite in the first cycle to be both on the second cycle (5) of students responded positive with both category on learning.
\end{abstract}

Copyright @ JCAE-Jurnal Tugas Akhir Mahasiswa, e-ISSN 2613-9782

Program Studi Pendidikan Kimia FKIP Universitas Lambung Mangkurat 
Keywords: critical thinking skill, learning outcomes, problem based learning, hydrocarbons.

\section{PENDAHULUAN}

Berdasarkan hasil wawancara dengan Ibu Heldaniah. Salah satu guru mata pelajaran kimia yang ada di SMA Negeri 10 Banjarmasin mengatakan, pada saat pembelajaran kimia berlangsung guru lebih sering berceramah, sehingga siswa kurang mampu menerima pelajaran disampaikan oleh guru pada saat proses pembelajaran berlangsung, siswa cenderung memperhatikan dan mencatat apa yang telah dipelajari. Seorang guru harusnya mampu mengajar dengan kreativitas dan tujuan pembelajaran yang diingkan tercapai, sehingga dimasa yang akan datang siswa dapat menjadi manusia unggul dan kritis. Maka dapat disimpulkan bahwa pembelajaran mampu diperbaiki menggunakan model pembelajaran yang benar dan menciptakan sesuatu dalam pembelajaran kimia yang belum pernah ada sebelumnya sangat penting dan diharapkan mampu membuat kemampuan berpikir kritis siswa dalam proses pembelajaran kimia meningkat. Menurut Kusasi (2016) kemampuan guru benarbenar sangat dibutuhkan terutama dalam upaya agar siswa mampu memahami konsepkonsep suatu ilmu pengetahuan termasuk kimia.

Berdasarkan informasi guru, materi hidrokarbon dianggap sulit oleh siswa, dari kemampuan kognitif siswa pada tahun pelajaran 2016/2017 sekitar 37\% hanya mencapai KKM $\leq 70$ saja. Hal ini disebabkan oleh, (1) siswa kurang mampu menentukan nama senyawa hidrokarbon (alkana, alkena, alkuna) sesuai dengan IUPAC, (2) Menentukan dan membedakan isomer senyawa alkana, alkena, alkuna, (3) menganalisis sifat kimia senyawa hidrokarbon, (4) faktor internal, dimana kebanyakan siswa kurang berperan aktif, kesadaran dan motivasi siswa selama pembelajaran berlangsung sehingga siswa kesulitan dalam memahami pembelajaran dan menganalisis soal yang guru berikan sehingga berdampak pada rendahnya hasil belajar siswa.

Menurut Delisle (dalam Abidin, 2014) model PBL salah satu model pembelajaran yang diterapkan guru untuk mengukur kemampuan siswa dalam berpikir dan kreativitas siswa dalam memecahkan masalah seiring dengan pembelajaran yang telah berlangsung. Siswa dapat berperan aktif di kelas dengan menggunakan model PBL, dengan cara melihat kemampuan berpikir siswa tentang masalah yang berkaitan dengan kehidupan sehari-harinya, mencari rancangan yang diperlukan untuk menemukan berbagai macam informasi yang dibutuhkan, membuat siswa memahami masalah, penyelesaian masalah yang bertujuan untuk memecahkan masalah, dan memberikan solusi masalah tersebut. Menurut Wati, Rusmansyah, Sholahuddin (2014) Model PBL mampu membuat siswa merangsang pikiran sehingga siswa mampu berpikir tingkat tinggi agar dapat menemukan penyelesaian masalah yang terjadi.

\section{METODE PENELITIAN}

Penelitian ini terlaksana melalui Penelitian Tindakan Kelas (PTK). Penelitian menggunakan dua siklus. Pada masing-masing siklus terjadi dua kali pertemuan, sehingga total setiap siklus menjadi empat kali pertemuan. Pengamatan dilakukan setiap pertemuan dan siklus akhir terjadi evaluasi. Penelitian dilakukan di pada kelas X-3 SMA Negeri 10 Banjarmasin berjumlah 35 orang terdiri dari 19 orang siswa dan 16 orang siswi. Objek penelitian meliputi aktivitas guru dan siswa, berpikir kritis dan hasil belajar, serta respon yang siswa berikan. 


\section{HASIL PENELITIAN DAN PEMBAHASAN}

Hasil yang didapat pada materi Hidrokarbon menggunakan model pembelajaran PBL dilaksanakan dalam dua siklus. Hasil penelitian berupa berpikir kritis dan hasil yang siswa peroleh dari tes di akhir pembelajaran siklus I dan siklus II.

Tabel 1. Pelaksanaan materi hidrokarbon

\begin{tabular}{|c|c|c|}
\hline Siklus & Waktu & Indikator \\
\hline & $\begin{array}{c}\text { Sabtu, } 15 \text { April } \\
2017\end{array}$ & $\begin{array}{l}\text { (1) Menjelaskan pemahaman tentang kekhasan atom } \\
\text { karbon dalam senyawa karbon. } \\
\text { (2) Menentukan unsur C primer, sekunder, } \\
\text { kuartener dan tersier dalam senyawa karbon. }\end{array}$ \\
\hline I & $\begin{array}{c}\text { Sabtu, } 22 \text { April } \\
2017\end{array}$ & $\begin{array}{l}\text { (1) Menjelaskan senyawa alkana dan alkena } \\
\text { (2) Menentukan penamaan senyawa alkana dan senyawa } \\
\text { alkena }\end{array}$ \\
\hline \multirow[b]{2}{*}{ II } & $\begin{array}{c}\text { Sabtu, } 29 \text { April } \\
2017\end{array}$ & $\begin{array}{l}\text { (1) Menuliskan penanamaan senyawa alkuna, } \\
\text { (2) Menentukan isomer stuktur (kerangka, posisi, fungsi) } \\
\text { dan ismoer geometri (cis dan trans) } \\
\text { (3) Menuliskan reaksi sederhana pada senyawa alkana, } \\
\text { alkena, alkuna }\end{array}$ \\
\hline & $\begin{array}{c}\text { Sabtu, 6 Mei } \\
2017\end{array}$ & $\begin{array}{l}\text { (1) Menjelaskan tentang minyak bumi } \\
\text { (2) Menjelaskan tentang bensin } \\
\text { (3) Menjelaskan penggunaan minyak bumi dan } \\
\text { dampaknya, } \\
\text { (4) Mengetahui kegunaan senyawa hidrokarbon dalam } \\
\text { sandang, pangan, perdagangan, seni, dan estetika }\end{array}$ \\
\hline
\end{tabular}

\section{Aktivitas Guru}

Penelitian aktivitas guru dinilai berdasarkan lembar aktivitas guru oleh beberapa observer. Hasil observasi aktivitas guru yang diperoleh pada siklus I dan siklus II tersaji pada Tabel 2.

Tabel 2. Skor aktivitas guru

\begin{tabular}{cccc}
\hline Siklus I & \multicolumn{2}{c}{ Siklus II } \\
\hline Pertemuan 1 & Pertemuan 2 & Pertemuan 1 & Pertemuan 2 \\
\hline 35,75 & 41,5 & 50,25 & 59,25 \\
Rata-rata $=38,62$ & \multicolumn{2}{c}{ Rata-rata $=54,75$} \\
Kategori $=$ Cukup & \multicolumn{2}{c}{ Kategori $=$ Sangat baik } \\
\hline
\end{tabular}

Siklus I aktivitas guru meningkat yaitu dari skor 38,62 dengan kategori cukup menjadi 54,75 dengan kategori sangat baik. Secara keseluruhan pembelajaran yang berlangsung pada pertemuan pertama berjalan lancar tetapi belum optimal.

Pada pertemuan kedua siklus I, aspek guru masih kurang maksimal dalam memberikan apersepsi, menyampaikan tujuan pembelajaran, mengarahkan siswa kepada masalah, membagi kelompok, mebimbing diskusi, meminta siswa mempresentasikan hasil diskusinya, menganalisis proses pemecahan masalah, mengevaluasi proses pemecahan masalah, dan menyimpulkan hasil pembelajaran sehingga guru masih mengatur keadaan kelas dan guru perlu memberikan umpan balik terhadap kinerja siswa agar siswa dapat memaahami pembelajaran. Hal ini sejalan dengan pendapat Selcuk (2010), model PBL adalah model yang menggunakan pendekatan selama proses pembelajaran yang membuat siswa menyelesaikan sebuah masalah seperti menyusun pengetahuan yang mereka dapat secara mandiri, siswa 
dapat mencari tahu jawaban sendiri dan kemampuan siswa dalam berpikir tingkat tinggi yang mendorong siswa berpikir lebih tinggi lagi, lebih mandiri dan siswa dapat percaya diri.

Aktivitas guru menggunakan model PBL pada siklus II dalam kategori sangat baik. Walaupun demikian, masih terdapat kekurangan pada pertemuan pertama siklus II. Pada saat guru menyampaikan apersepsi yang akan dipelajari sebagian siswa yang tidak memperhatikan guru dengan baik sehingga guru perlu mengatur keadaan kelas agar siswa yang memperhatikan tidak terganggu. Guru perlu membimbing siswa ketika guru mengarahkan siswa kepada masalah dan pada saat pembagian kelompok.

Hasil dari penelitian siklus I selama proses pembelajaran masih belum optimal, sehingga pada siklus II guru memperbaiki kesalahan dan hasil yang didapat meningkat pada aktivitas guru. Sejalan dengan penelitian Agustin (2013), menggunakan model PBL mampu membuat performasi guru meningkat.

\section{Aktivitas Siswa}

Aktivitas siswa dinilai berdasarkan kegiatan pembelajaran dilakukan siswa dalam menyatakan suatu tindakan. Penilaian aktivitas siswa dinilai berdasarkan lembar aktivitas siswa yang telah disediakan dan diteliti oleh empat orang observer tersaji pada Tabel 3.

Tabel 3. Skor aktivitas siswa

\begin{tabular}{cccc}
\hline \multicolumn{2}{c}{ Siklus I } & \multicolumn{2}{c}{ Siklus II } \\
\hline Pertemuan 1 & Pertemuan 2 & Pertemuan 1 & Pertemuan 2 \\
\hline 32 & 40,5 & 47,4 & 51,28 \\
Rata-rata $=36,12$ & Rata-rata $=49,37$ \\
Kategori $=$ Cukup & \multicolumn{2}{c}{ Kategori $=$ Sangat baik } \\
\hline
\end{tabular}

Siklus I terjadi peningkatan aktivitas siswa yaitu dari skor 36,12 mendapatkan kategori cukup menjadi 49,37 mendapatkan kategori aktif. Hasil analisis pada siklus I masih perlu diperhatikan dan diperbaiki. Aktivitas siswa siklus I termasuk kategori cukup.

Dapat dilihat dari siklus II ada kemajuan pada aktivitas siswa. Kekurangankekurangan aktivitas siswa selama proses pembelajaran siklus I perlu diperbaiki sehingga pembelajaran siklus II meningkat. Secara keseluruhan pada pertemuan satu siklus II aktivitas siswa cukup aktif menyebabkan kelas lebih tenang dan mampu dikendalikan selama proses pembelajaran siklus II. Hal ini sejalan dengan pendapat Uno (2012), lingkungan belajar mampu membut peserta didik lebih kondusif dan siswa jua belajar dengan baik, ini merupakan dorongan eksternal pemicu motivasi yang terjadi pada siswa. Tahap-tahap yang menunjukkan siswa secara aktif dalam mencermati apersepsi yang dijelaskan oleh guru, memahami materi yang disampaikan guru, menanggapi sanggahan guru, siswa juga telihat termotivasi dalam pembelajaran, berdiskusi dalam kelompok namun terdapat beberapa aspek yang belum efektif adalah siswa melakukan perencanaan masalah, menganalisis penyelesaian masalah, dan mengevaluasi penyelesaian masalah yang guru berikan. Penyebab kurang aktifnya siswa dalam beberapa aspek karena ada beberapa siswa yang tidak dapat memahami penjelasan yang guru berikan karena materi yang guru berikan semakin bertambah sulit tingkatan.

Aktivitas siswa dalam pertemuan kedua pada siklus II sangat meningkat. Hal ini sama dengan pendapat Wardoyo (2013), PBL adalah model pembelajaran dimana mengharuskan munculnya aktivitas yang membuat siswa bekerja secara aktif untuk menyelesaikan beberapa permasalahan yang dihadapi oleh siswa seperti membangun pengetahun dan pemahaman yang dimiliki. 
Afektif siswa

Hasil afektif siswa dinilai berdasarkan penilaian hasil lembar observasi afektif siswa. Rekapitulasi observasi afektif siswa siklus I dan II terjadi dua kali pertemuan tersaji di Tabel 4.

Tabel 4. Skor afektif siswa

\begin{tabular}{cccc}
\hline Siklus I & \multicolumn{2}{c}{ Siklus II } \\
\hline Pertemuan 1 & Pertemuan 2 & Pertemuan 1 & Pertemuan 2 \\
\hline 10,5 & 12,02 & 16,05 & 18,02 \\
Rata-rata $=11,08$ & Rata-rata $=17,03$ \\
Kategori $=$ Cukup & Kategori $=$ Sangat baik \\
\hline
\end{tabular}

Pada afektif siswa meningkat di siklus I dan siklus II, dimana siklus I afektif dengan skor 11,08 kategori cukup di siklus II skor 17,03 kategori sangat baik. Penilaian observer pada siklus II mengalami peningkatan. Terjadinya peningkatan karena adanya perbaikan guru selama mengajar dan respon yang ditunjukkan siswa meningkat selama guru mengajar di setiap pertemuan sehingga terjadi perubahan sikap yang lebih baik selama proses pembelajaran berlangsung. Hal ini sesuai pendapat Arends PBL merupakan model pembelajaran yang berkaitan melalui pendekatan pembelajaran pada masalah autentik sehingga siswa mampu merangkai pengetahuannya sendiri, mengemkembangkan keterampilan yang lebih tinggi dan siswa lebih aktif, siswa dapat menyelesaikan masalah secara mandiri dan mampu percaya kepada diri sendiri (Hosnan 2014). Selain itu penelitian ini sesuai dengan Tosun, \& Senocak (2013), bahwa PBL dapat memberi dampak yang signifikan dalam meningkatkan sikap positif.

Peningkatan afektif siswa pada penelitian ini mengalami perbaikan sehingga aktivitas siswa berhasil dilihat dari hasil pembelajaran di siklus I yang kurang optimal sehingga di siklus II aktivitas siswa meningkat.

\section{Berpikir Kritis}

Berpikir kritis siswa di siklus I kemampuan siswa dalam berpikir bervariasi. Hasil perhitungan kemampuan berpikir kritis siswa berdasarkan frekuensi yang diukur yaitu, 1 orang siswa tidak kritis, 10 orang siswa kurang kritis, 8 orang siswa cukup kritis, dan 16 orang siswa kritis, dan tidak ada kategori siswa yang sangat kritis. Kemampuan berpikir kritis siswa ada di Tabel 5.

Tabel 5. kemampuan berpikir kritis siklus I

\begin{tabular}{cccc}
\hline No. & Kategori & Frekuensi & Persentase (\%) \\
\hline 1 & Tidak kritis & 1 & 2,85 \\
2 & Kurang kritis & 10 & 28,57 \\
3 & Cukup kritis & 8 & 22,85 \\
4 & Kritis & 16 & 45,71 \\
5 & Sangat krits & 0 & 0 \\
\hline
\end{tabular}

Adapun persentase kemampuan berpikir kritis siswa menunjukkan 2,85\% siswa tidak kritis, 28,57\% siswa kurang kritis, 22,85\% siswa cukup kritis, 45,71\% siswa kritis dan $0 \%$ yang sangat kritis. Pada berpikir kritis siswa siklus II, kemampuan siswa dalam berpikir berbeda dengan siklus I. Berdasarkan frekuensi kemampuan berpikir siswa yaitu, tidak ada siswa yang tidak kritis, 1 orang siswa kurang kritis, 6 orang siswa cukup kritis, dan 19 orang siswa kritis, dan 9 siswa yang termasuk dalam kategori sangat kritis. Kemampuan berpikir kritis siswa ada di Tabel 6. 
Tabel 6. Kemampuan berpikir kritis siklus II

\begin{tabular}{cccc}
\hline No. & Kategori & Frekuensi & Persentase (\%) \\
\hline 1 & Tidak kritis & 0 & 0 \\
2 & Kurang kritis & 1 & 2,85 \\
3 & Cukup kritis & 6 & 17,14 \\
4 & Kritis & 19 & 54,28 \\
5 & Sangat krits & 9 & 25,71 \\
\hline
\end{tabular}

Adapun persentase kemampuan berpikir kritis siswa menunjukkan 0\% siswa tidak kritis, 2,85\% siswa kurang kritis, 17,14\% siswa cukup kritis, 54,28\% siswa kritis dan $25,71 \%$ yang sangat kritis. Kemampuan siswa berpikir kritis di siklus I dan siklus II meningkat, kemampuan berpikir kritis di siklus I 55,64\% kategori cukup kritis, sedangkan pada siklus II sebesar 71,74\% kategori kritis.

Secara klasikal persentase kemampuan berpikir kritis menggunakan model pembelajaran PBL pada siklus I dan siklus II meningkat 16,1\%. Sesuai yang dikemukakan oleh Abidin (2014), model pembelajaran PBL adalah pembelajaran dengan model yang bertujuan agar motivasi siswa meningkat dalam belajar, mampu membuat siswa berpikir tingkat tinggi, siswa memiliki kemampuan metakognisinya, dan pembelajaran menjadi berguna sehingga siswa percaya diri dan dapat belajar secara mandiri. Hal ini sejalan dengan penelitian Rahayu (2015), pembelajaran berbasis masalah dan pembelajaran berbasis penemuan tersebut mendukung guru untuk dapat mengatasi masalah yang selama ini dihadapi di dalam kelas.

Dengan harapan kedua pembelajaran tersebut dapat meningkatkan dan melatih kemampuan pemecahan masalah serta kemampuan berpikir kritis yang dibutuhkan siswa saat belajar. Adapun kemampuan siswa dalam berpikir kritis terjadi di siklus I dan siklus II tersaji di Tabel 7.

Tabel 7. Skor kemampuan berpikir kritis

\begin{tabular}{|c|c|c|c|}
\hline \multicolumn{2}{|l|}{ Siklus I } & \multicolumn{2}{|l|}{ Siklus II } \\
\hline Indikator & Rata-rata & Indikator & Rata-rata \\
\hline Memfokuskan pertanyaan & $53,09 \%$ & Memfokuskan pertanyaan & $70,23 \%$ \\
\hline Memutuskan suatu tindakan & $61,42 \%$ & $\begin{array}{l}\text { Memutuskan suatu tindakan } \\
\text { Mempertimbangkan laporan }\end{array}$ & $75,23 \%$ \\
\hline $\begin{array}{l}\text { Mempertimbangkan hasil } \\
\text { dedukasi }\end{array}$ & $54,28 \%$ & $\begin{array}{l}\text { observasi dan } \\
\text { mengidentifkasi } \\
\text { asumsi }\end{array}$ & $74,28 \%$ \\
\hline
\end{tabular}

Indikator 1 kemampuan berpikir kritis yang diukur adalah memfokuskan pertanyaan, yaitu membahas mengenai kemampuan siswa dalam merumuskan pertanyaan dengan jelas sesuai dengan indikator pembelajaran dan kasus dalam pertanyaan, serta dapat menghubungkan data-data dalam kasus atau pertanyaan. Indikator kemampuan berpikir kritis mengalami peningkatan di siklus I 53,09 dan di siklus II 70,23, dengan kenaikan 17,14. Adapun persentase dari siklus I dan siklus II 61,66 kategori kritis. Hal ini sejalan dengan penelitian Widyaningsih, Harjono, \& Airlanda (2018), menyatakan PBL merupakan pembelajaran dengan model, dimana model PBL mampu membuat siswa menyelesaikan permasalah agar terjadi peningkatan keterampilan siswa dalam berpikir secara kritis dan siswa dapat menyelesaikan masalah selain itu membantu siswa mengetahui pengetahuan yang baru dan pemahaman penting. Selain itu, dengan penelitian Khotimah, Suhartono, \& Salimi (2017), PBL siswa dapat diberikan atau menemukan sendiri permasalahan nyata dan mampu memecahan permasalahan tersebut.

Indikator 2 kemampuan berpikir kritis yang diukur adalah memutuskan suatu tindakan, yaitu membahas mengenai kemampuan siswa dalam memilih kriteria yang 
mungkin sebagai solusi permasalahan, selain itu mengenai kemampuan siswa dalam memutuskan suatu tindakan yang akan dilakukan. Indikator kemampuan siswa dalam berpikir kritis mengalami peningkatan dari siklus I $61,42 \%$ meningkat $75,23 \%$ di siklus II, dengan kenaikan $13,81 \%$. Adapun persentase dari siklus I dan siklus II sebesar $68,32 \%$ mendapatkan kategori kritis. Hal ini diperkuat oleh penelitian yang dilakukan Gholami, et. al (2016), bahwa dapat diketahui dari hasil penelitian ini tidak terjadi perubahan signifikan pada keterampilan berpikir kritis siswa melalui metode ceramah. Namun, setelah melakukan pembelajaran berbasis masalah $(P B L)$ terjadi peningkatan yang signifikan. Penelitian ini menunjukkan efek yang signifikan secara statistik untuk pembelajaran yang menggunakan PBL.

Indikator tiga pada kedua siklus berbeda. Pada siklus I indikator siswa yaitu mempertimbangkan hasil dedukasi. Tujuan dari indikator ini adalah menafsirkan data. Siswa diberikan data dan siswa harus menganalisis data tersebut. Data berupa jawaban seorang siswa ketika diperintahkan untuk menuliskan nama untuk masing-masing senyawa hidrokarbon, dan siswa dalam soal tersebut memberikan 3 jawaban yang nantinya akan dianalisis apakah semua jawaban siswa sudah benar atau tidak. Jika jawabannya belum benar maka tugas siswa adalah memperbaiki jawaban tersebut dan memberikan alasannya. Sedangkan pada siklus II indikator siswa yaitu mempertimbangkan laporan observasi dan mengidentifikasi asumsi. Dalam mempertimbangkan laporan observasi siswa mencari sumber-sumber untuk mencari informasi yang sesuai. Selain itu, indikator lainnya adalah mengidentifikasi asumsi yaitu membahasa mengenai kemampuan siswa dalam memahami konsep/masalah dan mengidentifikasi sebuah masalah yang diberikan pada soal dengan bukti dan alasan yang merunut. Indikator kemampuan berpikir kritis terjadi perubahan di siklus I $54,28 \%$ meningkat $74,28 \%$ di siklus II, dengan kenaikan $20 \%$. Adapun persentase siklus I dan siklus II 64,28\% kategori kritis. Hal ini sejalan dengan penilitian Happy, \& Widjajanti (2014), metode alternatif yang digunakan selama pembelajaran berlangsung, memberikan fasilitasi kemampuan dalam berpikir secara kritis contohnya dalam menerapkan PBL.

\section{Kognitif Siswa}

Pemahaman siswa dalam memahami materi hidrokarbon diukur dari hasil belajar siswa melalui tes diakhir siklus. Berdasarkan kategori ketuntasan, siswa yang tuntas $37,15 \%$ atau terdapat sebanyaka 13 siswa yang dapat memenuhi KKM, sehingga dilakukan perbaikan pada siklus II. Ketuntasan yang didapat dari tes siklus II meningkat. Ketuntasan pada siklus II sebesar 74,28\%, 26 siswa tuntas dan 25,72\% siswa tidak tuntas 9 orang. Gambaran ketuntasan yang didapat dari hasil belajar siswa pada siklus I dan siklus II disajikan pada persentase Gambar 1.

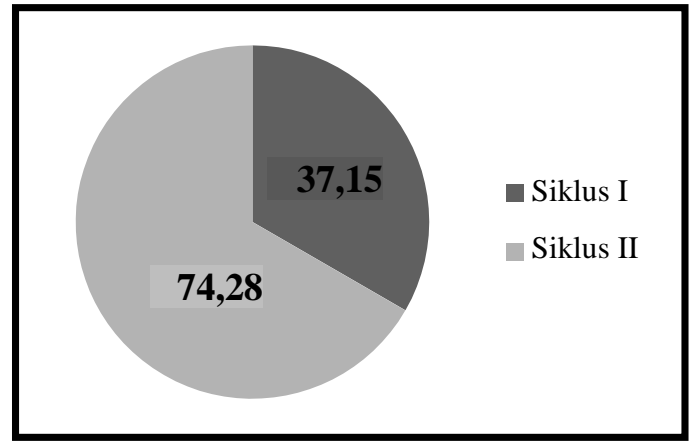

Gambar 1. Hasil belajar kognitif 
Model pembelajaran PBL materi hidrokarbon memudahkan siswa dalam memahami materi pembelajaran melalui kegiatan berdiskusi. Sehingga model PBL mampu membuat kemampuan siswa dalam berpikir secara kritis dan hasil belajar siswa meningkat. Sesuai pendapat Amir (2010), PBL memiliki prinsip yaitu pada langkah awal pembelajaran terdapat masalah yang harus diselesaikan, masalah terdapat dalam kehidupan sehari-hari, karna mampu meningkatkan hasil belajar siswa.

\section{Respon siswa}

Respon siswa terhadap model pembelajaran PBL untuk meningkatkan kemampuan siswa dalam berpikir secara kritis dan hasil belajar yang telah dipelajari pada materi hidrokarbon dapat dilihat dari angket respon siswa yang diberikan diakhir pembelajaran siklus II. Respon yang siswa berikan sebagian besar positif, dapat dilihat dari gambar 2.

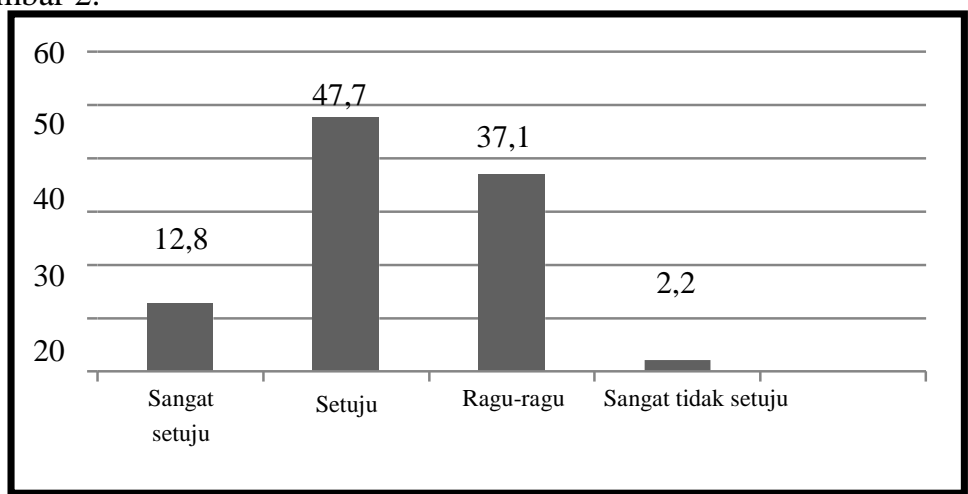

Gambar 2. Grafik Respon Siswa

Berdasarkan Gambar 2 respon siswa sangat setuju sebanyak 12,8\%, setuju sebanyak $47,7 \%$, ragu-ragu sebanyak $37,1 \%$, serta tidak setuju sebanyak $2,2 \%$. Hal ini sejalan dengan pendapat Choi, Lindquist, \& Song (2014), penggunaan model pembelajaran PBL ini membantu siswa dalam mengikuti proses pembelajaran. Dalam tahapannya siswa merasa mereka lebih mudah memahami pelajaran dengan langkahlangkah PBL seperti diskusi kelompok, persentasi, memberikan tanggapan dan menentukan strategi pemecahan. PBL membantu siswa mengembangkan pemikiran kritis untuk memecahkan masalah dalam pengaturan klinis mereka, dan menjembatani kesenjangan antara teori dan praktek

\section{SIMPULAN}

Berdasarkan penelitian yang dilakukan diperoleh hasil yaitu aktivitas guru, aktivitas siswa, afektif siswa, berpikir kritis, hasil belajar kognitif siswa dan respon siswa maka dapat disimpulkan bahwa model pembelajaran PBL mampu meningkatkan aktivitas guru, aktivitas siswa, afektif siswa, berpikir kritis, hasil belajar kognitif, dan siswa mampu merespon dengan baik.

\section{DAFTAR RUJUKAN}

Abidin, Y. (2014). Desain Sistem Pembelajaran dalam Konteks Kurikulum 2013. Bandung: PT Refika aditama.

Agustin, (2013). Peningkatan Aktivitas dan Hasil Belajar Siswa Melalui Model Problem Based Learning (PBL). Journal of Elementary Education.2(1): 39-43. 
Amir, T. (2010). Inovasi Pendidikan Melalui Problem Based Learning: Bagaimana Pendidik Memberdayakan Pemelajar di Era Pengetahuan. Jakarta: Kencana.

Choi, E., Lindquist, R., dan Song, Y. (2014). Effects of Problem-Based Learning vs. Traditional Lecture on Korean Nursing Students' Critical Thinking, ProblemSolving, and Self- Directed Learning. Nurse Education Today, 34(1): 52-56.

Gholami, M., Moghadam, K.P., Mohammadipoor, F., Tarahi, J. M., Sak, M., Toulabi, T., dan Pour., H. H. A. (2016). Journal Comparing The Effects of ProblemBased Learning and The Traditional Lecture Methode on Critical Thinking Skill and Metacognitive Awareness in Nursing Students in a Critical Care Nursing Course. Nurse Education Today, 45, 16-21.

Happy, N., dan Widjajanti, D. B. (2014). Keefektifan PBL Ditinjau dari Kemampuan Berpikir Kritis dan Kreatif Matematis, serta Self-Esteem Siswa SMP. Jurnal Riset Pendidikan Matematika, 1(1): 48-57.

Hosnan. (2014). Pendekatan Saintifik dan Kontekstual dalam Pembelajaran Abad 21. Bogor: Ghalia Indonesia.

Khotimah, K. Suhartono, S. dan Salimi., M. (2017). Penerapan Model Problem Based Learning untuk Meningkatkan Hasil Belajar Matematika Tentang Perkalian dan Pembagian Pecahan pada Siswa Kelas V SDN 1 Tamanwinangun Tahun Ajaran 2016/2017. Kalam Cendekia PGSD Kebumen, 5(2.1).

Kusasi, M. (2016). Strategi dan Model Berpikir Kritis (Critical Thinking) dan Pengembangannya.Proceeding Seminar Nasional Pendidikan IPA,

Rahayu, P. (2015). Eksperimentasi Model Problem Based Learning dan Discovery Learning pada Materi Perbandingan dan Skala Ditinjua dari Sikap Peserta Terhadap Matematika Didik Kelas VIII SMP Kabupaten Klaten Tahun Pelajaran 2013/2014. Jurnal Pembelajaran Matematika, 3(3).

Selcuk., G. Z. (2010). The Effects of Problem-Based Learning on Pre-Service Teachers'Achievment, Approaches and Attitudes Towards Learning Physics. International. Journal of The Physical Sciences. 5(6): 711-723.

Tosun, C., dan Taşkesenligil, Y.(2011). The Effect of Problem Based Learning on Student Motivation Towards Chemistry Classes and on Learning Strategies. Journal of Turkish Science Education. 9(1)

Uno., H. B. (2012). Teori Motivasi \& Pengukurannya. Jakarta: Bumi Aksara. Wardoyo., S. M. (2013) Pembelajaran Berbasis Riset. Jakarta: Akademia Permata.

Wati., R. Rusmansyah, dan Sholahuddin., A. (2014). Meningkatkan Kemampuan Berpikir Kritis dan Hasil Belajar Siswa Kelas XI IPA 2 SMA PGRI 4 Banjarmasin pada Konsep Sistem Koloid Melalui Model Problem Based Learning. Jurnal Inovasi Pendidikan Sains, 5(2): 20- 31.

Widyaningsih, Harjono, dan Airlanda. (2018). Jurnal Peningkatan Kemampuan Berpikir Kritis dan Hasil Belajar Tema 4 Menggunakan Model Problem Based Learning $(P B L)$ pada Siswa Kelas 5 SD Negeri Salatiga 01. 